\title{
Climate, Creatures and COVID-19: Environment and Animals in Twenty-First Century Media Discourse
}

\author{
REBECCA JONES, University of Strathclyde \\ Editor-in-Chief, Networking Knowledge
}

This special issue of Networking Knowledge was first conceived of in 2020, at the start of the first UK lockdown of the COVID-19 pandemic. It was a time during which the freedoms and spaces for movement of humans all over the world were radically altered in endless ways daily routines and professional lives disrupted, and family and social relationships inflected by the sudden necessity of digital communication. COVID-19 had, and continues to have, a profound effect on collective and individual health and physical and mental wellbeing, relationships, and politics and economies, all over the world. Inequality became further entrenched during the pandemic (Jenkins 2021; Coy 2021). It cost lives and livelihoods (World Health Organisation 2021; Sundaram 2020; Russon and Smith 2021), and the precarious circumstances in which many people already lived were exacerbated. COVID-19 has been characterised by loss of many kinds.

Loss on such a scale would, of course, make any reluctance to acknowledge the opportunities for pause, thought and discussion gained during the COVID-19 pandemic entirely understandable. Even more understandable, perhaps, is the uneasiness some may feel about considering the myriad human prejudices, complacencies and behaviours that contribute to creating crises like COVID-19 (Vidal 2020). The realisation that human (in)action may have contributed to or even caused the COVID-19 crisis is indeed deeply unsettling. It is, however, imperative to acknowledge this agency and reject defeatist inertia, because these are, in large part, the same (in)actions that are still contributing to another urgent crisis, marked by loss of habitat, loss of species, loss of homes and loss of security - climate change.

Reflecting on such things can be challenging, even when that reflection is limited to the hypothetical. There remains some defensiveness, scepticism and denialism about climate change and how it is being communicated in some parts of the media (see for example Booker 2018; Rose 2019). Could it be that, in some cases, a counter-intellectual resistance to the idea that such disasters have been, or can be, anthropogenic might be galvanised by the trauma of watching these crises unfolding even as we speak? Does witnessing the ever-growing of the storm make some of us even more reluctant to accept our role in its creation? Or is this scepticism simply a manifestation of complacency and disbelief - an undercurrent of insistence that real life is no big-budget disaster movie, and that things could never possibly be, or get, 'that bad'? Whatever the truth, the COVID-19 pandemic has had a manifest role in bringing conversations about subjects like zoonotic disease and anthropogenic climate change into the front and centre of public consciousness (see for example UN Environment Programme 2021; Constable and Kushner 2021). They may be gruelling, but these conversations are taking place. It remains important, however, to continue to consider who is having these conversations and 
where, what their vested interests and principles are, who is listening to whom, and who continues to lack a seat at the policy-making table. In other words, whose conversations count?

I am writing just a few weeks before the COP26 climate summit is due to take place in my home city of Glasgow. It is a moment in which climate change is particularly topical, when ever more column inches, blog and social media posts and television hours are being given over to the subject, and to speculating about and predicting what might emerge from the summit itself. The extent to which this investment in the subject will continue after COP26, of course, remains to be seen.

The event has not been without controversy, with some groups arguing that the global inequality of access to COVID-19 vaccination - what has become known as 'vaccine apartheid' - and soaring accommodation prices in Glasgow in the run-up to the event are effectively locking out less wealthy contributors to the conversation (Climate Action Network International 2020). Many official participants will arrive on environmentally damaging longhaul flights, the expense of which represent a significant investment for many non-profit organisations, and would be entirely unmanageable for the vast majority of the world's population. 'Uniting the world to tackle climate change', claims the landing page of the COP26 website (UN Climate Change Conference UK 2021) - but there have been significant concerns about who counts as the world in this case, and exactly who is being united. Grassroots events, marches and protests hosted by a plethora of organisations will, of course, take place around the summit itself, and the exponential increase in the capacity (and necessity) for social media and digital communication, debate and protest resulting from COVID-19 lockdowns will doubtless lend itself to greater online action during the summit - for those with digital access, at least. But it is important to recognise that these, for all of their very real and meaningful hard work, awareness-raising and changemaking, are occurring on the fringes of a space - physical, ideological and conceptual - where international goal-setting and policy decisions will continue to be made by the few, under the watchful eye of existing power dynamics and industrial lobbying which have yet to be dismantled. It remains to be seen whether, after so many previous COP events, the political gap between 'saying' and 'doing' will undergo a meaningful reduction.

As several of the articles in this special issue suggest, a commitment to interrogating homogenous references to 'humanity' that elide the inequalities at the intersections of sex, gender, race, ethnicity and disability that make human experience heterogenous is essential. There is a marked contrast in consumption levels between the so-called 'developed' and 'developing' worlds (Althor, Watson and Fuller 2016), and this has been thrown into everstarker relief by the COVID-19 pandemic, in areas including access to vaccines and economic recovery (Ghosh 2021). As causes of climate change are varied and contextual, workable solutions must be too. I suggest that it is also imperative that any recovery consistently interrogates anthropocentric, androcentric and capitalistic approaches to combatting both climate change and zoonotic pandemic.

The extent to which COP26 will consider the needs of non-human animal species in any meaningfully non-anthropocentric way, as sentient 'stakeholders' in the future of the planet rather than resources for human consumption, remains unclear. The Scottish animal welfare 
charity OneKind recently launched its \#COPOUT26 campaign to protest the 'glaring absence' of discussions about non-human animal species, and particularly the impact of animal agriculture on the climate, from the COP26 agenda (OneKind 2021). There have also been calls for the summit to serve an entirely plant-based menu in recognition of the significant impact that the meat and dairy industries have on the climate (Montague 2021; Baker 2021). So far, these appear to have gone unheeded. For now, then, it seems that non-human animal species - for whom climate change and the prevention of zoonotic disease are as critical as they are for humans - will remain on the table, rather than at it. While human decision makers continue to insist on their radical separation from the non-human world, and persist in refusing to centre non-human animals in any discussions about environmental justice on the basis of human exceptionalism, practical applications of theoretical interventions such as the entangled empathy imagined by Gruen (2015), the rendering-visible of the non-human animal 'absent referent' of Adams (2015) or the vital conception of non-human life (zoe) as theorised by Braidotti (2013) remain impossible.

A growing body of transdisciplinary academic ecological research exists, but much of it requires paid access, is restricted to a specialist audience, and/or is presented in language which limits accessibility. As a result, the non-specialist majority is particularly dependent on all forms of free-to-access media for information, education and entertainment about environment, climate and nature. The form, and free availability, of media has the power to prevent or encourage equality of access and grassroots organising to shape attitudes and policy. Nowhere is this more true than in discussions of climate change.

The role of media has been hotly debated and theorised in the context of COVID-19 - a search of Twitter hashtags such as \#scamdemic and \#plandemic reveals a considerable volume of scepticism of, and hostility to, 'mainstream' media reporting of the pandemic, lockdowns and vaccination drives. While there appears to be little evidence to suggest that this hostility is a majority view, its very existence still serves as a reminder that media framings of world events don't simply reflect conversations already happening in the wider population. They also shape those conversations, all the while exerting influence on those that might take place in future. There is a constant and pressing need to consider how the presence and absence of media voices during the current pandemic, and increased interest in environmental themes over the last few years, have informed public action, attitudes and even policy.

This special issue of Networking Knowledge features much-needed contributions to discussions about environment and ecology, particularly in the wake of the COVID-19 pandemic, the increasing urgency of the climate crisis, changed ways of working, communicating, and thinking and being in the world. These interventions are provided by postgraduate and early-career researchers from a range of disciplines. They are free-to-access, and it is our hope that they are also accessible to both academic and general audiences.

The contributions cover a range of subjects, from a range of theoretical standpoints, relevant to reflecting on the pre-COVID-19 world and what many of us might still perceive as a 'normal' to be returned to or reconfigured, the events of the pandemic and lockdown itself, and/or constructions of the future, and of the kind of recovery that is desirable and achievable. Maki Eguchi analyses a Japanese TV drama and its portrayal of pre-pandemic dairy farming, 
while Catherine Price considers genetically modified animals and the rhetorical construction of monstrosity. Lynda M Korimboccus asks us to consider animals in children's television, and the hypocrisy and cognitive dissonance of ham sandwiches in Peppa Pig lunchboxes. Xin Zhao questions how the notion of 'public' is constructed in the reporting of environmental justice policy in China, and Callum Bateson describes how the stories of Máiréad Ní Mhionacháin can help us to think about the importance of environmental belonging and the impact of colonialism in the Anthropocene. Tayler Zavitz and Corie Kielbiski juxtapose Bong Joon Ho's Okja (2017) and Karen Joy Fowler's We Are All Completely Beside Ourselves (2013) to analyse the power of entertainment media in creating attitudes about animal rights and welfare activism. Nivedita Tuli and Azam Danish show the role of Instagram in environmental justice, and how the platform can distort and appropriate environmental and animal rights and welfare campaigns into personal celebrity, marketing and other political agendas. Jack Buchanan offers an analysis of ecological practice and worldhood in the work of Welsh filmmaker Scott Barley, while Nikki E. Bennett and Elizabeth Johnson talk Tiger King, and the impact the series has (or hasn't) had on public engagement with, and attitudes to, the ownership of big cats for human entertainment. Theoretical work from critical animal studies, posthumanism, the environmental humanities and media studies is brought to bear on subjects that are relevant to how we have navigated - or failed to navigate - interspecies relationships and the entanglement of humans and ecology in the past, and how the pandemic might yet offer us an opportunity to reconsider and change direction. This special issue, then, isn't simply 'about COVID-19'. Rather, it contributes to a process of reflection, speculation and reimagining that is vitally important at this moment.

In presenting this special issue, made up of contributions to a discussion of our environment and interspecies relationships before, during and immediately after COVID-19, we pay our respects to those who have lost loved ones to the pandemic, those who have faced threats to their livelihoods, and those for whom this global event exacerbated existing injustices, whether they are human or non-human. We hope that these contributions to the discussion can help readers to imagine positive post-COVID-19 futures for the environment and climate, and all of the species who rely upon them for their survival. As ever, I extend deepest thanks to all of the authors, peer reviewers and members of the editorial team for their hard work in bringing this special issue to fruition.

\section{References}

Adams, C. (2015) The Sexual Politics of Meat: A Feminist-Vegetarian Critical Theory. Rev. edn. New York/London: Bloomsbury.

Althor, G., Watson, J. and Fuller, R. (2016) 'Global mismatch between greenhouse gas emissions and the burden of climate change', Sci Rep, 6 (20281). Available at:

https://doi.org/10.1038/srep20281

Baker, E. (2021) 'Over 50 Global NGOs Join Calls For COP26 To Go Plant-Based', Plant Based News, 1 September. Available at: https://plantbasednews.org/news/environment/over50-global-ngos-cop26-plant-based/ (Accessed: 1 October 2021). 
Bateson, C (2021) 'Folklore and the Climate Crisis: Reading Beara as an Anthropocene Patch with Máiréad Ní Mhíonacháin', Networking Knowledge: Journal of the MeCCSA Postgraduate Network, 14(2), pp. 110-123. Available at: https://doi.org/10.31165/nk.2021.142.644

Bennett, N.E and Johnson, E. (2021) 'The Potential for a "Tiger King Effect": Analysis of Public and Media Response to the Netflix Series Tiger King', Networking Knowledge: Journal of the MeCCSA Postgraduate Network, 14(2), pp. 124-146. Available at: https://doi.org/10.31165/nk.2021.142.642

Booker, C. (2018) 'Yes it's scorching, but claims that the heatwave is down to climate change are just hot air: June was even hotter when Victoria was on the throne', Mail Online, 25 July. Available at: https://www.dailymail.co.uk/debate/article-5992913/Yes-scorching-claimsheatwave-climate-change-just-hot-air-says-CHRISTOPHER-BOOKER.html (Accessed: 1 October 2021).

Braidotti, R. (2013) The Posthuman. Reprint. Cambridge, UK: Polity, 2015.

Buchanan, J. (2021) 'The Affective Database: Symulation and Enacting Worldhood in the Film-worlds of Scott Barley', Networking Knowledge: Journal of the MeCCSA Postgraduate Network, 14(2), pp. 147-159. Available at: https://doi.org/10.31165/nk.2021.142.645

Climate Action Network International (2021) Climate Action Network calls for postponement of formal COP26 negotiations due to lack of plans to ensure safe and inclusive participation. Available at: https://climatenetwork.org/2021/09/07/can-cop26-postponement-statement/ (Accessed: 1 October 2021).

Constable, H. and Kushner, J (2021) 'Stopping the next one: What could the next pandemic be?’, BBC Future, Available at: https://www.bbc.com/future/article/20210111-what-couldthe-next-pandemic-be (Accessed: 1 October 2021).

Coy, P. (2021) 'The Legacy of the Lost Year Will Be Devastating Inequality: Covid amplified every structural bias that exists', Bloomberg, 10 March. Available at: https://www.bloomberg.com/news/articles/2021-03-10/covid-pandemic-made-racial-incomeinequality-much-worse (Accessed: 1 October 2021).

Eguchi, M. (2021) 'Analysing Dairy Farming in Japan through the TV Drama Natsuzora (“Summer Sky")', Networking Knowledge: Journal of the MeCCSA Postgraduate Network, 14(2), pp. 8-23. Available at: https://doi.org/10.31165/nk.2021.142.647

Ghosh, J (2021) 'Vaccine apartheid: global inequities in Covid-19 vaccine production and distribution', Open Global Rights, 12 June. Available at: https://www.openglobalrights.org/vaccine-apartheid-global-inequities-in-covid-vaccine- 
production-and-distribution/ (Accessed: 12 October 2021).

Gruen, L. (2015) Entangled Empathy: An Alternative Ethic for Our Relationships with Animals. New York: Lantern Books.

Jenkins, S. (2021) 'Covid has made inequality even worse. The only answer: squeeze the super-rich', The Guardian, 26 January. Available at:

https://www.theguardian.com/news/commentisfree/2021/jan/26/covid-inequality-worsesqueeze-super-rich (Accessed: 1 October 2021).

Korimboccus, L. M. (2021) 'Animal Representation on UK Children's Television', Networking Knowledge: Journal of the MeCCSA Postgraduate Network, 14(2), pp. 41-64. Available at: https://doi.org/10.31165/nk.2021.142.651

Montague, B. (2021) 'COP26: Meet don't meat', The Ecologist, 19 August. Available at: https://theecologist.org/2021/aug/19/cop26-meet-dont-meat (Accessed: 1 October 2021).

OneKind (2021) COPOUT26. Available at: https://www.onekind.scot/campaigns/copout26/ (Accessed: 8 October 2021).

Price, C. (2021) 'The Online Genetically Modified Food Debate: Sociotechnical Imaginaries and Genetically Modified Animals', Networking Knowledge: Journal of the MeCCSA Postgraduate Network, 14(2), pp. 24-40. Available at: https://doi.org/10.31165/nk.2021.142.641

Rose, D. (2019) 'What David Attenborough told BBC viewers about this raging orangutan fighting a digger is only part of the truth ... and that's just one of the flaws in the great naturalist's 'alarmist' new documentary', Mail Online, 20 April. Available at: https://www.dailymail.co.uk/news/article-6943475/What-Attenborough-told-BBC-viewersorangutan-fighting-digger-truth.html

(Accessed: 1 October 2021).

Russon, M and Smith, O. (2021) 'We're in serious trouble, says hospitality industry', BBC News, 14 June. Available at: https://www.bbc.co.uk/news/business-57476419 (Accessed: 1 October 2021).

Sundaram, A. (2020) 'Yelp data shows $60 \%$ of business closures due to the coronavirus pandemic are now permanent', $C N B C, 16$ September. Available at: https://www.cnbc.com/2020/09/16/yelp-data-shows-60percent-of-business-closures-due-tothe-coronavirus-pandemic-are-now-permanent.html (Accessed: 1 October 2021).

Tuli, N. and Danish, A. (2021) 'Construction of Natures and Protests on Instagram: A Study of Virtual Environmental Activism in India During the COVID-19 Pandemic', Networking Knowledge: Journal of the MeCCSA Postgraduate Network, 14(2), pp. 160-191. Available at: 
UN Climate Change Conference UK 2021 (2021) Available at: https://ukcop26.org (Accessed: 1 October 2021).

UN Environment Programme (2020) Preventing the next pandemic - Zoonotic diseases and how to break the chain of transmission. Available at:

https://www.unep.org/resources/report/preventing-future-zoonotic-disease-outbreaksprotecting-environment-animals-and (Accessed: 1 October 2021).

Vidal, J. (2020) '“Tip of the iceberg”: is our destruction of nature responsible for Covid-19?', The Guardian, 18 March. Available at:

https://www.theguardian.com/environment/2020/mar/18/tip-of-the-iceberg-is-ourdestruction-of-nature-responsible-for-covid-19-aoe (Accessed: 12 October 2021).

World Health Organisation (2021) WHO Coronavirus (COVID-19) Dashboard. Available at: https://covid19.who.int (Accessed: 1 October 2021).

Zavitz, T. and Kielbiski, C. (2021) 'Animal Oppression and Solidarity: Examining Representations of Animals and Their Allies in Twenty-First Century Media', Networking Knowledge: Journal of the MeCCSA Postgraduate Network, 14(2), pp. 95-109. Available at: https://doi.org/10.31165/nk.2021.142.643

Zhao, X. (2021) 'How "public" is communicated in China's public diplomacy: communicating environmental justice in the case of air pollution in China', Networking Knowledge: Journal of the MeCCSA Postgraduate Network, 14(2), pp. 65-94. Available at: https://doi.org/10.31165/nk.2021.142.629

Rebecca Jones is a $\mathrm{PhD}$ researcher in English at the University of Strathclyde. Her thesis, 'Consuming Men: Masculinity, Meat and Myth in Literary Fictions from Mary Shelley to Ursula K. Le Guin', uses ecofeminist critical animal studies to analyse human-animal interconnections, masculinity, 'meat' and species in literary retellings of the Prometheus myth since Frankenstein. Rebecca's interest is mainly in science fiction, fantasy and dystopian and utopian fiction. Rebecca holds an MA (Hons) and MLitt in Classics from the University of Glasgow and an MLitt in Gender Studies from the University of Stirling. She is the Editor-in-Chief of the MeCCSA Postgraduate Network journal Networking Knowledge, Coordinator of the Glasgow Women's Library Book Group and Founder and Coordinator of the Feminist Reading Group.

Email: rebecca.jones@strath.ac.uk 